\title{
Linking Flow Regime, Floodplain Lake Connectivity and Fish Catch in a Large River-Floodplain System, the Volga-Akhtuba Floodplain (Russian Federation)
}

\author{
K. E. van de Wolfshaar, ${ }^{1,2,3 *}$ H. Middelkoop, ${ }^{2}$ E. Addink, ${ }^{2}$ H. V. Winter, ${ }^{3}$ \\ and L. A. J. Nagelkerke ${ }^{1}$
}

\begin{abstract}
${ }^{1}$ Aquaculture and Fisheries Group, Wageningen University, Marijkeweg 40, 6709 PG Wageningen, The Netherlands; ${ }^{2}$ Department of Physical Geography, Utrecht University, Heidelberglaan 2, 3584 CS Utrecht, The Netherlands; ${ }^{3}$ Imares, Wageningen UR, Haringkade 1, 1976 CP IJmuiden, The Netherlands
\end{abstract}

\begin{abstract}
River-floodplain systems are amongst the most productive-but often severely impacted-aquatic systems worldwide. We explored the ecological response of fish to flow regime in a large riverfloodplain system by studying the relationships between (1) discharge and inundated floodplain area, with a focus on spatial and temporal patterns in floodplain lake connectivity, and (2) flood volume and fisheries catch. Our results demonstrate a non-linear relationship between discharge and floodplain inundation with considerable hysteresis due to differences in inundation and drainage rate. Inundation extent was mostly determined by flood volume, not peak discharge. We found that the more isolated lakes (that is, lakes with a shorter connection duration to the river) are located at higher local elevation and at larger hydrological distance from the main rivers: geographical distance to the river appears a poor predictor of lake
\end{abstract}

isolation. Although year-to-year fish catches in the floodplain were significantly larger with larger flood volumes in the floodplain, they were not in the main river, suggesting that mechanisms that increase catch, such as increased floodplain access or increased somatic growth, are stimulated by flooding in the floodplain, but not in the river. Fish species that profit from flooding belong to different feeding guilds, suggesting that all trophic levels may benefit from flooding. We found indications that the ecological functioning of floodplains is not limited to its temporary availability as habitat. Refugia can be present within the floodplain itself, which should be considered in the management of large rivers and their floodplain.

Key words: floodplain; connectivity; habitat; fish catch; flood pulse; hydro-ecology; river management.
Received 23 December 2010; accepted 11 May 2011; published online 3 June 2011

Author Contributions: KEW designed and performed the research, and wrote the manuscript, HM and LAJN contributed to analyses and writing, EA contributed to methods of satellite analyses and writing, and HVW contributed to writing.

*Corresponding author; e-mail: Karen.vandewolfshaar@wur.nl

\section{INTRODUCTION}

River floodplains are highly productive ecosystems that suffer from human impact worldwide (Junk and others 1989). Regulation of river flow regimes has resulted in homogenizing of flooding dynamics, 
which caused habitat degradation and reduced habitat diversity in many floodplains (Poff and others 1997; Bowen and others 2003, Poff and others 2007). Numerous fish species use floodplains for spawning, as nursery and as foraging habitat. Fish recruitment and somatic growth correlate positively with flood magnitude and the size of inundated area (Gutreuter and others 1999; Sommer and others 2001; Schramm and Eggleton 2006; Probst and others 2009; Van de Wolfshaar and others 2010). Moreover, fish catch biomass tends to increase with increasing connectivity of floodplain water bodies to the main river. Species composition differs amongst water bodies with different connectivity (Amoros and Roux 1988; Grift 2001; Miranda 2005), with fish diversity becoming larger with increasing connectivity (Amoros and Bornette 2002).

Despite growing evidence that habitat availability and diversity promote fish production and species diversity in river-floodplain systems, management decisions on river flow regimes are primarily driven by the demands for hydropower, irrigation, navigation and safety (Vasilevskii and others 2001; Poff and others 2007). Management of river-floodplain systems aiming at sustainable populations, diversity and catches of fish, demands a sound understanding of the relationship between hydrological management and ecological response, that is, between river discharge, flood volume, floodplain inundation patterns and fish production (Amoros and Roux 1988; Gutreuter and others 1999; Frazier and Page 2009). However, such analyses are still in their infancy (compare Ligon and others 1995; Schramm and Eggleton 2006). Although the importance of the flood-pulse concept has been widely recognized (Junk and others 1989; Poff and others 1997), quantification of the relationship between river discharge and floodplain inundation patterns, including water body connectivity, has received little attention in the context of ecological functioning of river-floodplain systems (Vaughan and others 2009).

In this study, we analyzed the relationships between the managed flow regime and floodplain inundation patterns, water body connectivity and fish catches in the lower Volga River (Russian Federation) and its floodplain. First, we determined the relationship between river discharge and floodplain inundation patterns, with emphasis on spatial and temporal patterns in floodplain lake connectivity, using satellite image analyses. Second, we related variations in annual fish catches to flood volume, discriminating between separate fish species, and between catches from the main river and from floodplain water bodies. We hypothesized that an increase in available foraging habitat in the floodplain promotes fish biomass, which is reflected in higher fish catch. Underlying this hypothesis is the assumption of positive relationships between flood volume and inundated area, and between flood volume and water body connectivity. A positive relationship between flood volume and caught biomass in the same year could result from mechanisms such as more fish using the inundated habitat (for example, due to increased access), and increased somatic growth of individual fish using this habitat (for example, due to increased productivity and food availability) (De Graaf 2003a; Schramm and Eggleton 2006).

\section{METHODS}

\section{Study Area}

The Volga River (Russian Federation) is the largest river in Europe with a length of $3660 \mathrm{~km}$ and average annual discharge of $8500 \mathrm{~m}^{3} / \mathrm{s}$. It has a combined rainfall/snowmelt flow regime, with a peak discharge in May-June. The construction of a cascade of dams in the Volga River, completed in the 1960s, has changed the natural flow of the Volga River, but the regime with spring peak flow has remained (Ratkovich and others 2003; Górski and others 2011). Directly downstream of the Volgograd dam the Volga divides into the Lower Volga, which is the main channel, and the Akhtuba, a smaller distributary. The rivers run almost parallel, and bound the Volga-Akhtuba floodplain (VAF) down to the delta in the Caspian Sea (Figure 1). The floodplain extends over a length of $300 \mathrm{~km}$, is $10-30 \mathrm{~km}$ wide and is incised in the surrounding steppe area bounded by $30 \mathrm{~m}$ high cliffs. The study area is the $100-\mathrm{km}$ upstream part of the Volga-Akhtuba floodplain located just downstream of the dam, with a size of $1800 \mathrm{~km}^{2}$. The Akhtuba River is the main contributory of water to the floodplain, rather than the Lower Volga itself. During a flood, river water feeds from the upper Akhtuba into the floodplain in the northwestern part of the area (Figure 1) via a network of channels and streams, thereby connecting numerous floodplain lakes. Most water is retained in the central and more eastern parts of the floodplain, which are somewhat lower than the western area and consist of wet and moist grasslands, helophytes and marsh vegetation. The western and southern parts consist of a combination of wet and dry grasslands, floodplain forest, some small villages and (abandoned) agricultural fields (Janssen and 


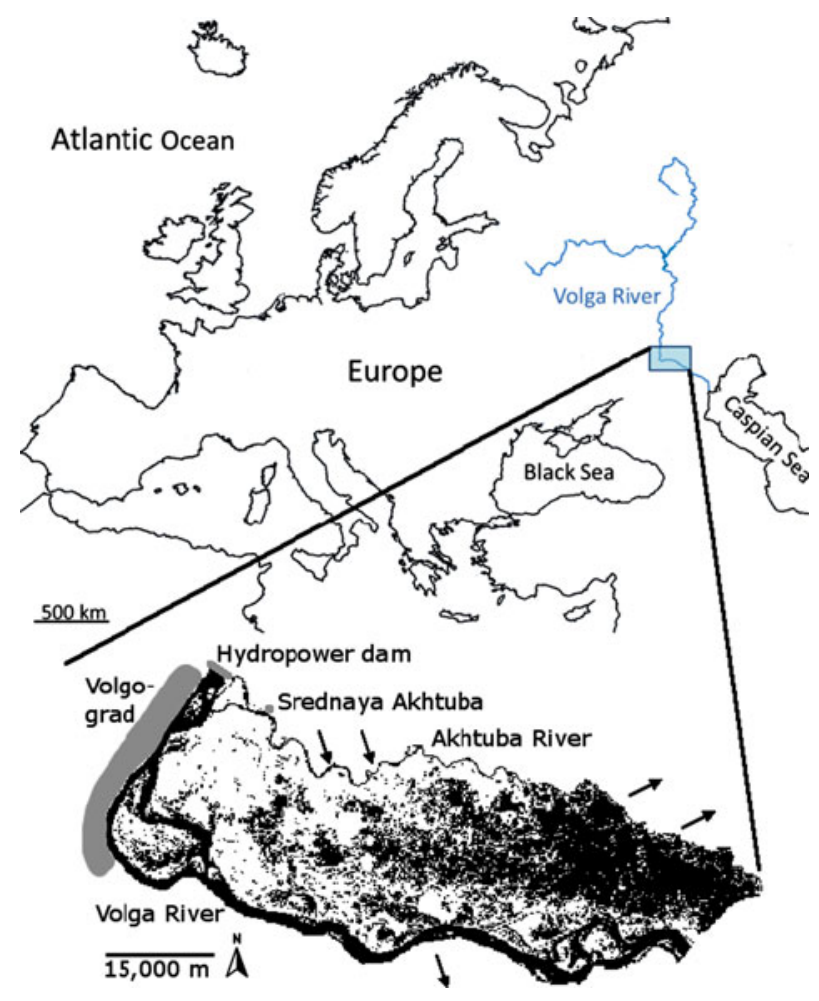

Figure 1. Map of the study area in the Volga-Akhtuba floodplain in Russia and its position in Europe. The bottom image shows the floodplain area embedded between the Volga River in the south and the Akhtuba River in the north, with water in black (Landsat image 19-052001, $\left.Q=27100 \mathrm{~m}^{3} / \mathrm{s}\right)$. The arrows indicate the areas where the water enters and leaves the floodplain.

others 2000). When the discharge decreases at the end of a flood, most water in the eastern part drains into the Akhtuba River, whereas a minor part flows into the Volga towards the south. The floodplain soils are dominated by clay in flood basins, sandy and silty loam and loamy sand nearby floodplain channels, with a remarkable absence of coarse sand and gravel (Chalov 2004; Middelkoop 2005; Ivanov and others 2006). Ground water levels within the floodplain are on average at 3-4 m below the surface, and show about $2 \mathrm{~m}$ fluctuations along with discharge variations. However, because of the low permeability of the substrate, the highest ground water levels are only reached by the end of June, thus considerably delaying the dynamics of the surface water (Levashova and others 2004).

\section{Fish and Fisheries}

The river-floodplain system contains a diverse flora and fauna, including at least 26 fish species of which a large number are of commercial interest (Ratkovich and others 2003). The floodplain catches are dominated by eurytopic species such as common bream (Abramis brama), white bream (Blicca bjoerkna), perch (Perca fluviatilis) and roach (Rutilus rutilus), and limnophilic species such as pike (Esox lucius), whereas the Volga catches consist mostly of bream and more rheophilic species such as asp (Aspius aspius) and ide (Leuciscus idus) (Table 1) (Górski and others 2011).

Commercial fishery in the area is based on permits granted by the local fisheries commission. Fishing typically occurs at the end of summer when the floodplain area is drained and most permanent water bodies become isolated from the rivers, making them accessible for cars and tractors. Floodplain fishery consists of pulling a seine net of approximately $50 \mathrm{~mm}$ stretched mesh, attached to two tractors, which drive towards each other around a water body, thereby clearing the water body of most of the fish of catchable size. The Volga River catches are done in a similar manner using tractors and netting from the shore. Consequently, the fished surface area is limited by the length of the nets and because the same nets are used for several years the fished surface area will have been more or less similar from year-to-year. Apart from the horse power of the tractors these methods have not changed much in years. Since the number of permits and gear did not change abruptly from year-to-year, it can be expected that the total fishing effort was similar in subsequent years (pers. comm. Sergey Yackovlev, Head Fisheries Institute GosNIORCH, Volgograd, Russian Federation).

\section{Data}

Daily discharge data, from 1960 to 2007, of the Volgograd Hydropower Station, and water levels at Srednaya Akhtuba gauging station (located on the Akhtuba River $10 \mathrm{~km}$ downstream of its bifurcation from the Volga River, Figure 1) were obtained from the Volgograd Centre of Hydrometeorology and Environmental Monitoring, Volgograd, Russian Federation. In addition, we obtained monthly discharge data from 1901 to 1920 at Volgograd from the ORNL DAAC (Vörösmarty and others 1998), representing the natural flow regime before dam construction. Based on a field survey, the water level in the Volga that results in a water flow into the floodplain channels was determined at $-6.5 \mathrm{~m}$ Baltic Ordnance Datum, corresponding to a discharge of $18000 \mathrm{~m}^{3} / \mathrm{s}$ (Górski and others 2011). A flood event in the VAF starts with water entering the floodplain channel and stream network. From these channels, streams and the Akhtuba River overbank flow occurs onto the floodplain grasslands. We defined flood events as the period during 
Table 1. Species Present in Floodplain and Volga River Catches (\% Catch) and Their Ecological Guild

\begin{tabular}{|c|c|c|c|c|c|c|}
\hline Species name & & $\begin{array}{l}\text { Flow } \\
\text { preference }\end{array}$ & $\begin{array}{l}\text { Reproductive } \\
\text { guild }\end{array}$ & Feeding guild & $\begin{array}{l}\text { Floodplain c } \\
\text { atch }(\%)\end{array}$ & $\begin{array}{l}\text { Volga } \\
\text { catch }(\%)\end{array}$ \\
\hline Asp & Aspius aspius & $\mathrm{Eu}$ & $\mathrm{Li}$ & $\mathrm{Pla} / \mathrm{Ben} / \mathrm{Pis}$ & 1.5 & 27.2 \\
\hline Bleak & Alburnus alburnus & $\mathrm{Eu}$ & Po & Pla/Ben & 0.5 & 0.0 \\
\hline Blue bream & Ballerus ballerus & RhB & $\mathrm{Pl}$ & Pla & 4.6 & 2.9 \\
\hline Burbot & Lota lota & RhB & $\mathrm{Li} / \mathrm{Pe}$ & Ben/Pis & 0.0 & 0.0 \\
\hline Chub & Leuciscus cephalus & RhA2 & $\mathrm{Li}$ & Ben/Pis/Phy & 0.7 & 1.0 \\
\hline Common bream & Abramis brama & $\mathrm{Eu}$ & Po & $\mathrm{Pla} / \mathrm{Ben}$ & 15.3 & 31.4 \\
\hline Common carp & Cyprinus carpio & $\mathrm{Eu}$ & $\mathrm{Ph}$ & Ben/Pla/Phy & 1.3 & 0.1 \\
\hline Gibel carp & Carassius gibelio & $\mathrm{Eu}$ & $\mathrm{Ph}$ & Ben/Phy/Det & 3.6 & 0.7 \\
\hline Grass carp ${ }^{1}$ & Ctenopharyngodon idella & RhB & $\mathrm{Pe}$ & Phy/Det & 0.1 & 0.0 \\
\hline Ide & Leuciscus idus & RhB & $\mathrm{Pl}$ & Ben/Pis/Phy & 1.4 & 5.9 \\
\hline Perch & Perca fluviatilis & $\mathrm{Eu}$ & $\mathrm{Pl}$ & $\mathrm{Pla} / \mathrm{Ben} / \mathrm{Pis}$ & 13.7 & 1.6 \\
\hline Pike & Esox lucius & $\mathrm{Eu}$ & $\mathrm{Ph}$ & $\mathrm{Pla} / \mathrm{Pis}$ & 7.3 & 3.0 \\
\hline Pike-perch & Sander lucioperca & $\mathrm{Eu}$ & $\mathrm{Ph}$ & $\mathrm{Pla} / \mathrm{Ben} / \mathrm{Pis}$ & 2.8 & 7.8 \\
\hline Roach & Rutilus rutilus & $\mathrm{Eu}$ & Po & Pla/Ben/Phy & 27.1 & 5.1 \\
\hline Rudd & Scardinius erythrophthalmus & Lim & $\mathrm{Ph}$ & Ben/Phy & 3.9 & 0.5 \\
\hline Ruffe $^{2}$ & Gymnocephalus cernuus & $\mathrm{Eu}$ & $\mathrm{Pl}$ & Ben & 0.1 & 0.0 \\
\hline Sabrefish & Pelecus culltratus & RhB & $\mathrm{Pe}$ & Pis & 0.5 & 1.9 \\
\hline Silver carp ${ }^{1}$ & Hypophthalmichthys molitrix & RhB & $\mathrm{Pe}$ & Phy/Det & 0.1 & 0.0 \\
\hline Tench & Tinca tinca & Lim & $\mathrm{Ph}$ & Ben/Phy/Det & 1.7 & 0.0 \\
\hline Volga nase $^{1}$ & Chondrostoma variabile & RhA2 & $\mathrm{Li}$ & Phy/Det & 0.1 & 1.5 \\
\hline Volga pikeperch & Sander volgensis & Lim & $\mathrm{Pl}$ & $\mathrm{Pla} / \mathrm{Ben} / \mathrm{Pis}$ & 0.5 & 0.6 \\
\hline Wels catfish & Silurus glanis & $\mathrm{Eu}$ & $\mathrm{Ph}$ & Ben/Pis & 2.6 & 3.8 \\
\hline White bream & Blicca bjoerkna & $\mathrm{Eu}$ & $\mathrm{Ph}$ & Ben/Phy/Det & 10.8 & 3.8 \\
\hline White-eye bream & Ballerus sapa & RhB & $\mathrm{Li}$ & Ben & 0.2 & 0.4 \\
\hline
\end{tabular}

which the water level at the Srednaya Akhtuba station exceeds the channel bankfull threshold.

A digitized topographic map of the floodplain (scale 1:100000, Atlas Volgograd Oblast USSR, 1988) was used in combination with a Landsat TM 5 satellite image acquired in summer (date 200107-06) after recession of the large flood filling all lakes to identify and map all floodplain lakes, streams and channels in the study area. A digital elevation map of SRTM data (http://srtm.csi.cgiar.org), which was resampled to $300 \times 300 \mathrm{~m}$ resolution to reduce very local elevation differences, was used to determine relative differences in elevation within the floodplain. Lake altitude was corrected for the slope of the area, which has a downstream terrain gradient of $5.5 \mathrm{~cm} / \mathrm{km}$ (Middelkoop 2005).

To determine floodplain inundation patterns resulting from different discharge situations we used a series of Landsat TM4, TM5 and TM7 images (http://glovis.usgs.gov/) of the Volga-Akhtuba floodplain acquired between 1985 and 2007. Images were chosen such that they covered the whole range of discharges from base to peak levels. This selection resulted in 19 usable images of the floodplain area, each with $30 \times 30 \mathrm{~m}^{2}$ cell size (Table 2).

Annual catches of 24 commercially important fish species (Table 1) from the Volga River and floodplain water bodies were obtained from the Volgograd Fisheries Inspection for the period 19592002 (Figure 2).

\section{Flood Patterns and Lake Connectivity}

After geo-referencing the satellite images (root mean squared error $<30 \mathrm{~m}$ ), all satellite images were segmented into water or no-water, providing the inundated area of the VAF for each image. We used the unsupervised ISODATA clustering method, a standard automated algorithm (Lillesand and others 2008), using 10 classes for low-water images, and using 20 classes for high-water images to distinguish inundated areas from swampy vegetation. The segmentation results were validated by documenting inundated areas during extensive 
Table 2. Variables Concerning Discharge, Inundation and Flood Duration Relating to the Date of the Image and the Year the Image was Taken, Based on Daily Discharge Data

\begin{tabular}{lllllll}
\hline Date image & $\begin{array}{l}\text { Landsat } \\
\text { sensor }\end{array}$ & $\begin{array}{l}Q \text { at date } \\
\text { image }\left(\mathrm{m}^{3} / \mathrm{s}\right)\end{array}$ & $\begin{array}{l}\text { Inundated } \\
\text { area }\left(\mathrm{km}^{2}\right)\end{array}$ & $\begin{array}{l}\text { Day number } \\
\text { relative to date } Q_{\max }\end{array}$ & $\begin{array}{l}Q_{\max } \text { in year } \\
\text { image }\left(\mathrm{m}^{3} / \mathrm{s}\right)\end{array}$ & $\begin{array}{l}\text { Flood duration } \\
\text { in year image (days) }\end{array}$ \\
\hline $15-05-1985$ & TM5 & 26000 & 959.36 & 3 & 28100 & 44 \\
$18-07-1985$ & TM5 & 9940 & 250.17 & 67 & 28100 & 44 \\
$02-05-1986$ & TM5 & 28100 & 938.79 & 2 & 28100 & 45 \\
$03-06-1986$ & TM5 & 16900 & 685.59 & 34 & 28100 & 45 \\
$06-06-1987$ & TM5 & 21300 & 803.25 & 21 & 26200 & 39 \\
$02-05-1989$ & TM4 & 24000 & 478.30 & -2 & 26100 & 33 \\
$05-05-1993$ & TM5 & 26800 & 665.08 & -4 & 28100 & 41 \\
$22-06-1993$ & TM5 & 7490 & 305.91 & 44 & 28100 & 41 \\
$27-05-1995$ & TM5 & 18400 & 836.30 & 30 & 28100 & 51 \\
$13-05-1996$ & TM5 & 13000 & 315.70 & -6 & 24100 & 9 \\
$14-06-1996$ & TM5 & 5030 & 230.78 & 26 & 24100 & 9 \\
$01-04-2001$ & TM7+ & 9030 & 117.39 & -22 & 25940 & 14 \\
$19-05-2001$ & TM7+ & 27100 & 814.29 & 16 & 28000 & 45 \\
$06-07-2001$ & TM7+ & 8110 & 172.84 & 64 & 28000 & 45 \\
$25-05-2003$ & TM7+ & 17000 & 709.571 & 15 & 26000 & 34 \\
$22-09-2003$ & TM5 & 5820 & 128.98 & 135 & 26000 & 34 \\
$13-08-2006$ & TM5 & 5190 & 143.88 & 100 & 18300 & 4 \\
$12-05-2007$ & TM5 & 17020 & 368.42 & 19 & 25940 & 14 \\
$28-05-2007$ & TM5 & 17060 & 331.25 & 35 & 25940 & 14 \\
\hline
\end{tabular}

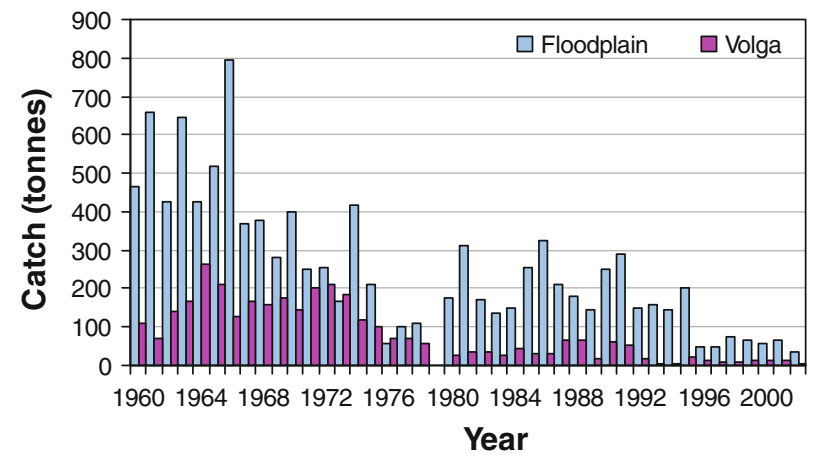

Figure 2. Volga River and floodplain commercial catches (in tonnes).

field surveys carried out in spring and summer of 2006 and 2007 in the floodplain and along the Volga and Akhtuba Rivers. The segmented satellite images were further checked with field observations to correct the channel network for dams, culverts and bridges that were not detected from the satellite images. A major road crosses the floodplain from north to south and appears well on the satellite images. The road is located on an embankment that forms a barrier in the floodplain. To reconstruct the connections between the flood waters on either side of the embankment, the channels passing the road underneath bridges were separately digitized from topographic maps scale
1:100000 and added to the satellite-derived network.

From each satellite image, a grid map was created indicating for each cell the distance via water to the nearest main river, Volga or Akhtuba. Subsequently, by overlaying the map of floodplain water bodies onto each distance map, the distance of individual water bodies to the main rivers was derived, resulting in a dataset of lake connectivity for all flood stages represented by the satellite images. Connectivity was then classified into five categories post hoc, based on the size of the inundated area and the duration of the lakes' connection derived from the series of images: (1) regular: lakes connected on all images; (2) flood: lakes connected on images with an inundated area larger than $300 \mathrm{~km}^{2}$; (3) peak flood: lakes connected on images with an inundated area larger than $700 \mathrm{~km}^{2}$; (4) peak incident: lakes connected on images with an inundated area larger than $900 \mathrm{~km}^{2}$; (5) not connected: lakes that are not connected to the main rivers on any image. The resulting classification was then correlated with spatial patterns of (1) the downstream distance from the Volga-Akhtuba bifurcation (along the river slope), (2) the geographical distance from either Volga or Akhtuba River and (3) the local elevation of the floodplain surface surrounding the water body. For the lateral distance of the lakes to the main rivers, we used the geographical distance 'as the crow flies'. In 
addition, we determined both the minimum and the maximum hydrological distance to the main rivers, based on the distances over water for each water body to the main rivers derived from the satellite images as described above. The correlations between connectivity and geographical and hydrological distances were determined using multinomial regression (logit model). Furthermore, we analyzed the spatial patterns in minimum and maximum hydrological distance using ANOVA. We tested the relationships between different connectivity classes and hydrological and geographical distance using binomial regression.

Because of the non-linear relationship between discharge and inundated area (Figure 3) we used the inundated area in the connectivity analysis rather than the upstream Volga River discharge.

\section{Fish Catch and Inundation Patterns}

Since we hypothesized that a larger inundated area promotes the use of the floodplain and somatic growth due to increased foraging habitat availability, we expected that extensive floodplain inundation results in increased catch of fish biomass. However, fish catch is not only dependent on the biomass present, but also on the fishing effort. Because formal statistics of fishing effort were not available, it was impossible to determine whether observed long-term changes in catch are due to changes in effort only or also to changes in fish biomass. However, given the nature of commercial fishing in the Volga River and the floodplain, with limited and licensed access, it is unlikely that fishing effort will have changed strongly from 1 year to the next, although there is anecdotal evidence that there is a long-term decrease in (officially sanctioned) fishing effort (pers. comm. Fisheries Institute GosNIORCH, Volgograd, Russian Federation). Therefore, we compared catch differences between subsequent years, assuming that extensive floodplain inundation in year $i$ is likely to result in increased catch of fish biomass in year $i$ compared to year $i-1$ with a smaller extent of floodplain inundation, and vice versa. By differencing the long-term statistics of fish catches, the data are de-trended and this enables focusing on year-to-year differences in catch statistics. To standardize the variability around the long-term trends in catches, fish catches were first $\log _{\mathrm{e}}$-transformed before differencing. The catch data for years $i$ and $i-1$ that were correlated with floodplain inundation were, therefore, of the form $\log _{\mathrm{e}}\left(C_{i}\right)-\log _{\mathrm{e}}\left(C_{i-1}\right)$, which equals $\log _{\mathrm{e}}\left(C_{i} / C_{i-1}\right)$. Direct estimates of the inundated area or the duration of inundation were not
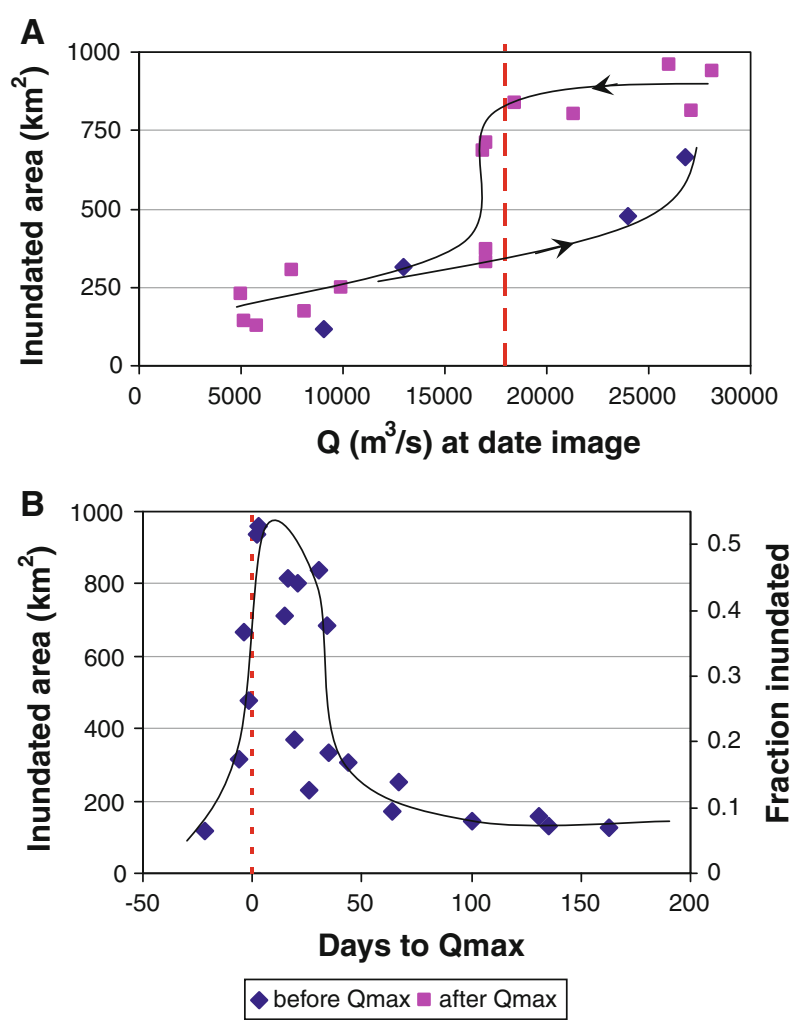

Figure 3. A Relationship between inundated area in the Volga-Akhtuba floodplain and the discharge at the date of the satellite image. Black diamonds refer to images taken before the peak discharge, grey squares refer to images taken after the peak discharge. The dashed line denotes the discharge threshold above which the floodplain gets inundated. The black lines are hand drawn curves to illustrate the difference between inundation and drawdown phase. B Relationship between inundated area (absolute and fraction) and the number of days before or after the date of annual maximum discharge, for each satellite image. The fine dashed line denotes zero days to $Q_{\max }$. The black line is a hand drawn curve to illustrate the shape of the relationship.

available for all years with catch data. Therefore, we used a proxy for flooded area by calculating the flood volume for each year, which is the cumulative daily discharge above the discharge level for which the bankfull threshold is exceeded (Górski and others 2011). Regressions of $\log _{\mathrm{e}}\left(C_{i} / C_{i-1}\right)$ against $\log _{\mathrm{e}}$ (flood volume) were performed. Before regression, time series of $\log _{\mathrm{e}}$-transformed catch data and flood volume were checked for auto-correlation using Durbin-Watson statistics (Vinod 1973). In case no autocorrelation was detected, we performed regressions without additional transformation of the data. When autocorrelation was detected, however, we corrected for this by applying stepwise autoregression using a Yule-Walker correction (Gallant and Goebel 1976). First we fitted a 
high-order autoregressive model. Second, we sequentially removed autoregressive parameters until all remaining parameters were statistically significant. Residuals from the autoregressive models (now without autocorrelation) were then regressed against flood volume.

All spatial analyses were carried out with Erdas 9.2, with the exception of the connectivity and distance analysis, which were calculated using PCRaster (Karssenberg and others 2001). Statistical analysis was done with SAS 9.2 (SAS 2004).

\section{RESUlTS}

\section{Discharge and Area Inundation}

The area of floodplain water bodies within the Volga-Akhtuba floodplain varies between 100 and $350 \mathrm{~km}^{2}$ (about $7 \%$ of the floodplain area) as long as the Volga River discharge remains below the bankfull threshold (Figure 3A). This area comprises the perennially wet lakes and floodplain channels. Above the threshold, the inundated area increases with discharge. Because of a higher rate of water inflow and inundation compared to the rate of drainage of the floodplain, the relationship between inundated area and discharge above the bankfull level shows anti-clockwise hysteresis (Figure 3A). With increasing inflow of water into the floodplain, a progressively larger area begins to inundate. Over time, the area of largest inundation shifts from the west to the low-lying eastern part of the floodplain. At a certain point in time, a maximum inundation area seems to be reached. As long as the incoming water flow continues to provide water-even when the recession of the discharge peak has started-the large area remains inundated. However, as soon as the upstream discharge drops below the threshold level and the incoming water flow stops, the size of the inundated area decreases rapidly.

Ground water appears to play a very minor role in the inundation of the floodplain. Both in the satellite images and during the field surveys, we observed that floodplain lakes re-fill and become connected to the other lakes and floodplain channels through overland flow. Lake level rise due to feeding by rising ground water levels was not observed. Moreover, in the field we occasionally observed large differences in water levels between nearby lakes, when one of them was filled by surface water reaching the lake from the floodplain channels. Apparently, the rise of the flood waters entering the floodplain is much faster than the associated ground water response. This delayed effect is confirmed by the general observation that the maximum ground water levels are only reached by the end of the flood period (Levashova and others 2004), and are due to the low permeability and conductivity of the underlying clayey and silty floodplain deposits.

To reconstruct the within-season change in inundated area based on the satellite images taken at different dates and in different years, we expressed the acquisition date of the images by the number of days relative to the date of the peak discharge $\left(Q_{\max }\right)$. The resulting compilation indicating inundated area in the course of a discharge peak shows that the largest areas of inundation occurred close to the date of $Q_{\max }$ (Figure 3B). The period of increased inundated area lasts about 50 days, after which the base level is reached again. At peak discharge over $50 \%$ of the area remains inundated (Figure 3B). These satellite-derived results thus demonstrate that the annual variation in flood volume and duration explain the variation in the size of inundated area during flooding.

\section{Lake Connectivity}

During the dry period about 80 lakes remain connected to the Volga or Akhtuba rivers, whereas during the large flood of 1985-3 days after the peak discharge-2259 lakes were connected. The relationship between the number of connected lakes and inundated area is linearly increasing above a threshold of around $300 \mathrm{~km}^{2}$ (Figure 4A). During low-water periods, the hydrological distance of connection varies largely between the few connected lakes (Figure 4B). This is due to the fact that at low discharges only the major channels are connected to the main rivers. However, these channels reach far into the floodplain, thereby connecting some lakes over large distances. When inundation of the floodplain starts, the number of connected lakes rapidly increases, whereas at the same time the distance by which lakes are connected decreases to an average of $10 \mathrm{~km}$. Remarkably, with progressively larger inundation area and inherent number of lakes connected to the rivers, the average distance to the main rivers remains unchanged (Figure 4B). Apparently, although the pathway to inundated lakes shortens over time, new, more remote lakes become connected, keeping the average distance largely unaltered.

As the data did not allow precise determination of annual durations of increasing inundation extents, we grouped lakes based on connectivity. Each year more than $50 \%$ of all lakes are connected to the main rivers during the flood 

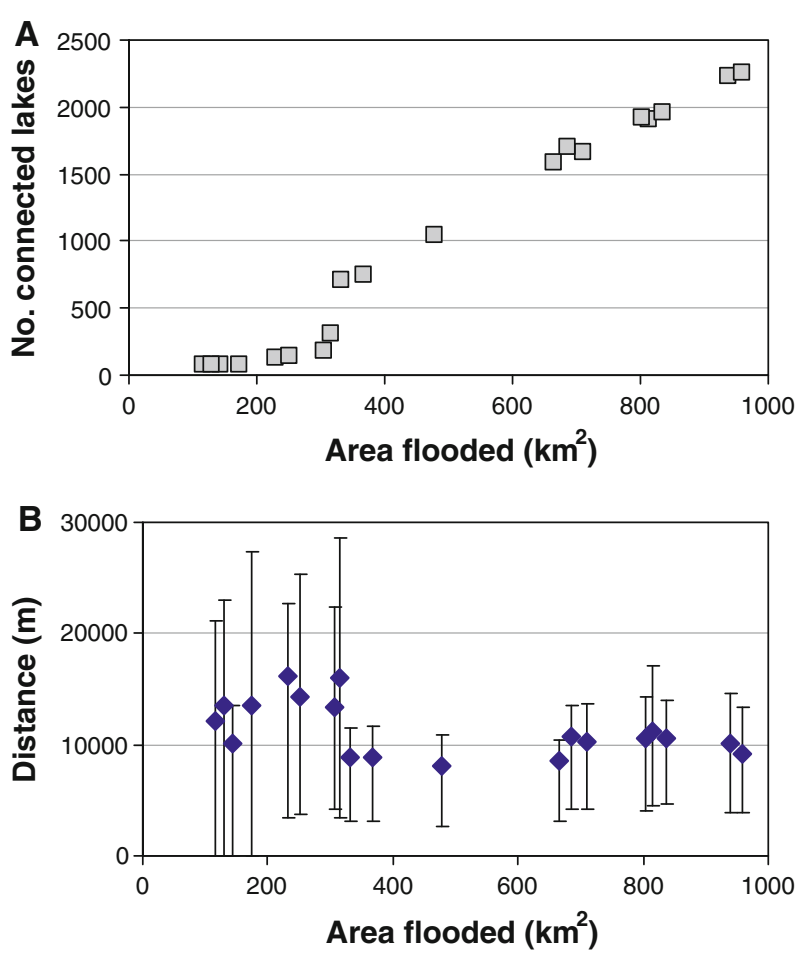

Figure 4. A Number of lakes connected to the Volga or Akhtuba River as a function of inundated area. B Hydrological distance of connected lakes to Volga or Akhtuba as a function of inundated area, presented as average, 0.25 and 0.75 percentile.

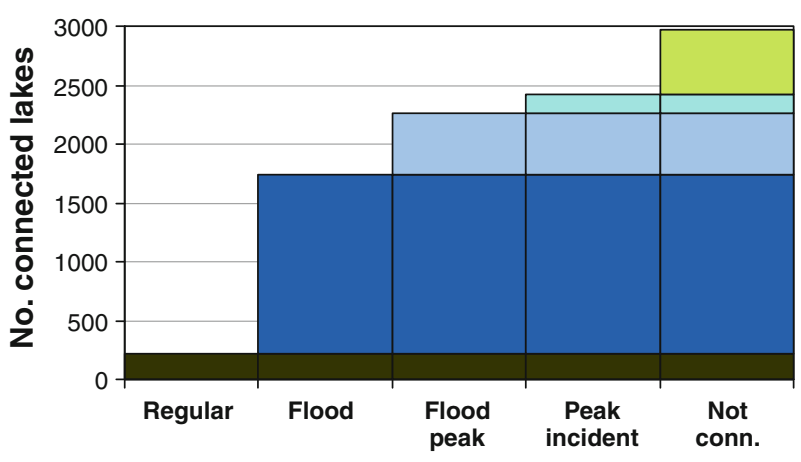

Figure 5. Number of lakes per connection duration class: regular: lakes connected for inundated area larger than $100 \mathrm{~km}^{2}$; flood: lakes connected for inundated area larger than $300 \mathrm{~km}^{2}$; flood peak: lakes connected for inundated area larger than $700 \mathrm{~km}^{2}$; peak incident: lakes connected for inundated area larger than $900 \mathrm{~km}^{2}$; not connected: lakes not connected or connected only on 1 occasion not during a flood event.

(Figure 5A). Over 500 lakes are connected to the main rivers only during the short period of peak discharge (area $>700 \mathrm{~km}^{2}$ ), whereas an additional 164 lakes only become connected when the inundated area exceeds $900 \mathrm{~km}^{2}$ ('peak incident'). Based on the satellite image analysis, 553 lakes are not connected at all; apparently these are connected to ground water all years and through temporary connections that were not visible on the images.

The spatial distribution of connection duration of the floodplain lakes shows a clear pattern (Figure 6). In general, the connection duration slightly increases in a downstream direction and with decreasing floodplain elevation, but the correlations with these variables are weak (Table 3). Isolated lakes, either 'not connected' or only connected during 'peak incident' (>900 km² inundated area), are located mostly in the western part of the area and mostly at large hydrological distances, whereas lakes that connect for the duration of a flood are mostly located in the eastern part and at short hydrological distance (Figure 6; Table 4). Regularly connected lakes occur throughout the area and at short hydrological distance (Table 4). There is no correlation between the geographical distance and connection duration (Table 3), although most lakes connecting only during the flood peak are located in the southern part of the area (Figure 6). The minimum hydrological distance explains the larger part of the variation in connection duration. There is a negative trend between increased connection duration and increased distance, whereas the maximum hydrological distance and the geographical distance are significant but weak predictors (Table 3). The hydrological distance of lakes to the Volga or Akhtuba River shows a clear spatial pattern, primarily with a positive trend with the geographical distance to the main channels, with a secondary positive trend in downstream distance (increased duration with increased distance), whereas the negative relationship with floodplain elevation is weak (increased duration with decreased elevation) (Table 3). In general, lakes that are more rarely connected to the rivers are located at greater distance from the Volga or Akhtuba River than regularly connected lakes.

Historic data on the natural flow regime of the Volga River show the profound effects of damming and river regulation on the discharge (Figure 7). Due to regulation, base flow increased from 2000 to $6000 \mathrm{~m}^{3} / \mathrm{s}$, whereas average flood discharge decreased from 27000 to $21000 \mathrm{~m}^{3} / \mathrm{s}$, and flood duration was reduced from nearly 2 months to 1 month (Figure 7). Together with our data on floodplain inundation and lake connectivity (for example, Figures 3-5), we conclude that in the pre-damming period floodplain inundation extended over larger areas and lasted for a longer period of time. It is likely that more lakes 


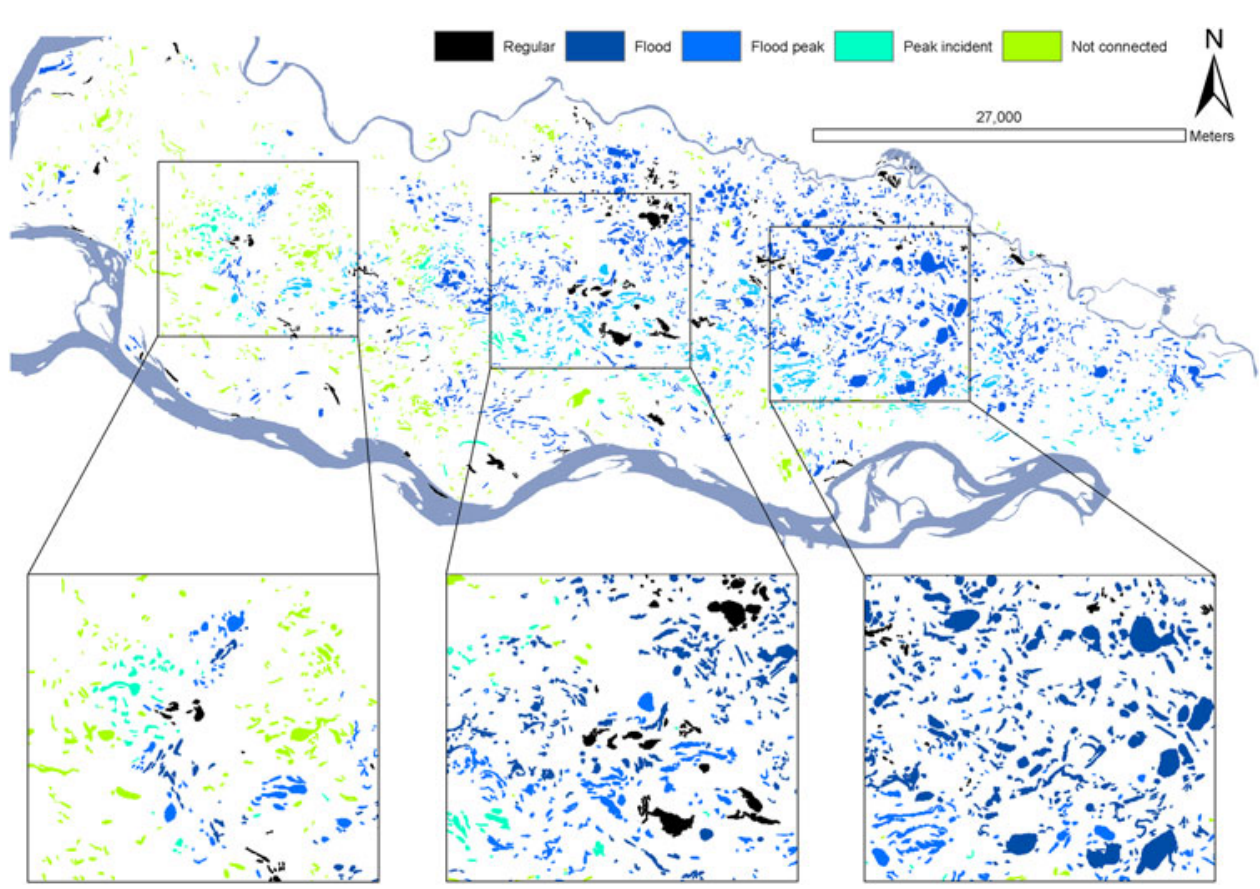

Figure 6. Spatial distribution of the lakes per connection duration class: regular: lakes connected for inundated area larger than $100 \mathrm{~km}^{2}$; flood: lakes connected for inundated area larger than $300 \mathrm{~km}^{2}$; flood peak: lakes connected for inundated area larger than $700 \mathrm{~km}^{2}$; peak incident: lakes connected for inundated area larger than $900 \mathrm{~km}^{2}$; not connected: lakes not connected or connected only on 1 occasion not during a flood event.

Table 3. Results of the Statistical Analysis for Connection Duration of Floodplain Lakes and Spatial Patterns and Hydrological Distances (Minimum and Maximum) (Multinomial Regression), and Analysis of Spatial Patterns in Hydrological Distance (ANOVA)

\begin{tabular}{|c|c|c|c|c|c|c|}
\hline Dependent variable & Independent variable & AIC & Odds ratio & $P$ & $R^{2}$ & Trend \\
\hline \multirow[t]{5}{*}{ Connection duration $(n=2974)$} & Downstream distance & 7766 & 1.039 & $<0.0001$ & 0.14 & + \\
\hline & Floodplain elevation & 7766 & 0.779 & $<0.0001$ & 0.11 & - \\
\hline & Geo. distance & 4773 & 0.855 & $<0.0001$ & 0.06 & - \\
\hline & Min. hydro. distance & 4446 & 0.869 & $<0.0001$ & 0.17 & - \\
\hline & Max. hydro. distance & 4863 & 0.974 & $<0.0001$ & 0.02 & - \\
\hline
\end{tabular}

\begin{tabular}{|c|c|c|c|c|}
\hline Dependent variable & Independent variable & $P$ & $R^{2}$ & Trend \\
\hline \multirow[t]{3}{*}{ Min. distance $(n=2421)$} & Downstream distance & $<0.0001$ & 0.34 & - \\
\hline & Geo. distance & $<0.0001$ & 0.55 & + \\
\hline & Floodplain elevation & $<0.0001$ & 0.08 & - \\
\hline \multirow[t]{3}{*}{ Max. distance $(n=2421)$} & Downstream distance & $<0.0001$ & 0.23 & - \\
\hline & Geo. distance & $<0.0001$ & 0.44 & + \\
\hline & Floodplain elevation & $<0.0001$ & 0.04 & - \\
\hline
\end{tabular}

Table 4. Relationship between Connection Duration Classes and Downstream and Minimum Hydrological Distance

\begin{tabular}{|c|c|c|c|c|c|c|}
\hline \multirow[t]{2}{*}{ Connection duration class } & \multicolumn{3}{|c|}{ Downstream distance } & \multicolumn{3}{|c|}{ Minimum hydrological distance } \\
\hline & $P$ & $R^{2}$ & Trend & $P$ & $R^{2}$ & Trend \\
\hline Regular $(n=209)$ & 0.1665 & 0.0006 & + & 0.0356 & 0.0019 & - \\
\hline Flood $(n=1533)$ & $<0.0001$ & 0.1133 & + & $<0.0001$ & 0.1327 & - \\
\hline Flood peak $(n=515)$ & $<0.0001$ & 0.0117 & + & $<0.0001$ & 0.0625 & - \\
\hline Peak incident (164) & $<0.0001$ & 0.0169 & - & $<0.0001$ & 0.0917 & + \\
\hline Not connected $(n=553)$ & $<0.0001$ & 0.2021 & - & & & \\
\hline
\end{tabular}




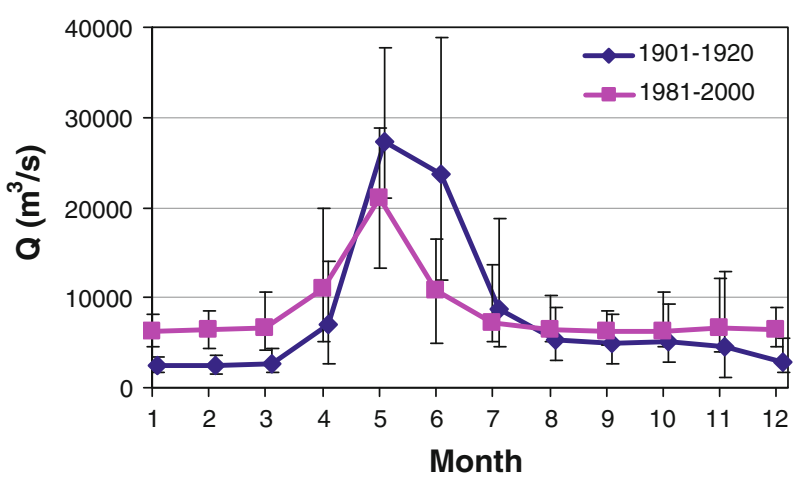

Figure 7. Historic and current average monthly discharges at the Volgograd hydropower dam (minimum and maximum values are given as error bar).

were connected during flooding and for longer periods.

\section{Flood Volume and Fish Catches}

There is no significant autocorrelation in the time series of flood volume $(P>0.11$ and $|r|<0.25$ for all autoregressive orders); therefore, the values of flood volume were not corrected for autocorrelation. In the 43 time series of relative fish catches that could be tested, significant autocorrelation is present in 26 series (Table 5). Seventeen of these series have an autoregressive order of 1, but autoregressive orders up to 4 are found (Table 5). All autocorrelations are negative and range between -0.35 and -0.97 . The application of the YuleWalker correction in the autoregressive models leads to residuals without autocorrelation in all tested time series. Regression of either these residuals, or the relative catches (in case there was no autocorrelation) against flood volume results in statistically significant positive correlations in floodplain water bodies, both for total catches ( $\left.n=41, R^{2}=0.54, P<0.00001\right)$, as well as for eight species which add up to greater than $65 \%$ of total fish catch in the floodplain (Table 5; Figure 8). Catches of these species are larger in years when more water enters the floodplain compared to catches in the preceding year when less water enters the floodplain. In the Volga River such a relationship is not found for total catches, nor for any of the species, except for gibel carp (Carassius gibelio). Although the Volga River catches of gibel carp significantly increase with flood volume, this is not the case in the floodplain. In contrast, catches of asp, which dominates the Volga catch, do not increase with flood volume in the Volga, whereas they do so in the floodplain catches, despite the low asp abundance there. Interestingly, bream, a species very common in both catches only has a positive relationship with flood volume for the floodplain catch and not for the Volga catch.

\section{Discussion}

The manner by which management affects ecological floodplain functioning in general is indirect, and operates via discharge and inundation patterns. In this study, we addressed the relationship between discharge and inundation patterns in space and time, and the inherent relationship between flood magnitude and ecological functioning in terms of fish catch. Although the Volga-Akhtuba floodplain experiences a managed flow regime, it can be considered semi-natural when compared to most western European rivers, where the flow is even more modified and floodplains are often no longer available for aquatic organisms (Aarts and others 2004; Middelkoop and others 2005). The Volga-Akhtuba floodplain has a unique layout, in the sense that two main rivers bound the floodplain area, opposite to more commonly occurring systems where the river has floodplains on either side. In these systems, the width of the floodplain has been limited by artificial embankments, especially in more populated areas. The spatial patterns in habitat connection in the Volga-Akhtuba floodplain represent those occurring in natural-unconstrained-floodplains, and may represent a reference situation for rivers with unnaturally narrow, embanked floodplains.

The results presented here show a general trend that lakes connecting for shorter periods connect over larger distances (Figures 5, 6). Remarkably, mean connectivity of floodplain lakes is larger in the downstream direction than with increasing geographical distance to the main rivers. We consider the annual average duration of the connection of floodplain lakes to the rivers as the keycriterion for the degree of isolation versus connectivity, as it determines how long exchange of water and biota may occur. Due to the local geomorphology, such as the location of floodplain channels, natural levees, pointbars or small embankments, the hydrological distance between floodplain lakes and the rivers shows a large spatial variability over short distances, and may greatly change with increasing inundation extent (Figure 6). The complex floodplain topography makes the geographical distance ('as the crow flies') between floodplain lakes and the main channel an unsuitable measure for the degree of isolation/ connection. Instead, the hydrological distance is a better predictor for connection duration, but this 


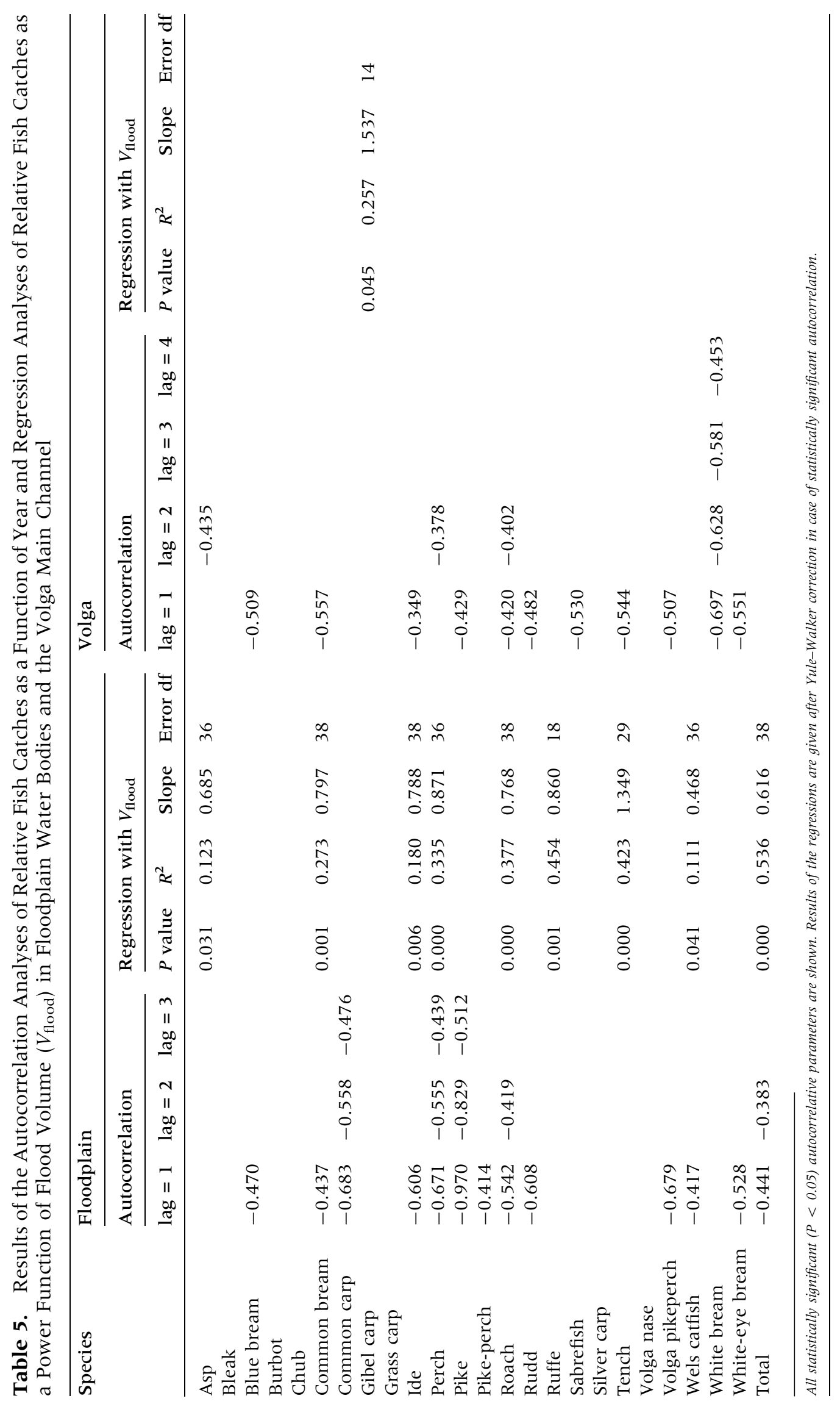



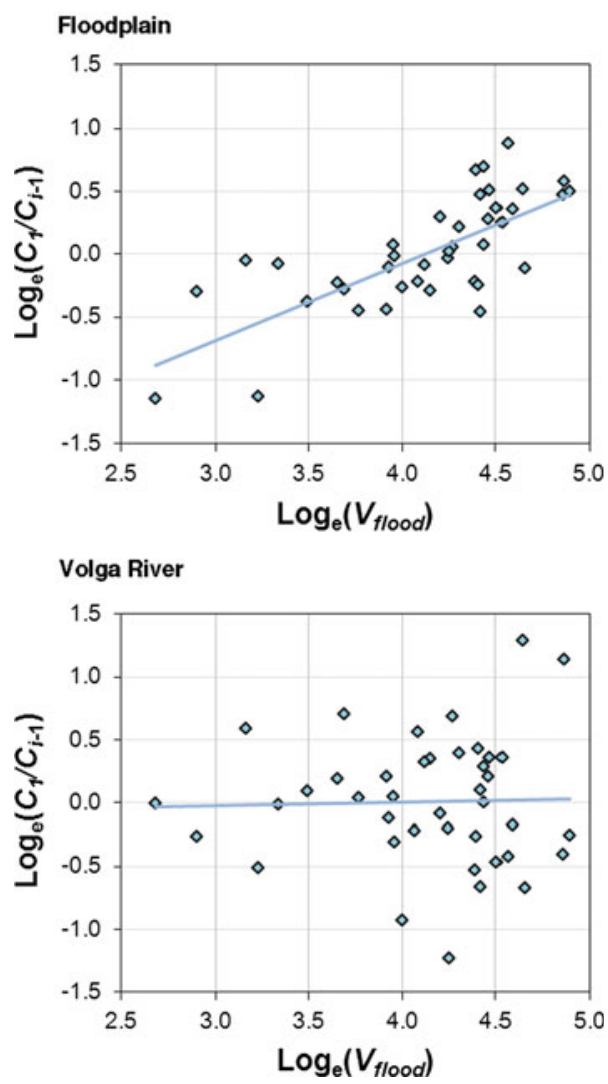

Figure 8. Relationship between log flood volume (annual cumulative daily discharge above the bankfull threshold) and the $\log _{\mathrm{e}}$-transformed difference between catches of subsequent years for the post-damming period 1960-2002. The solid line is a second power function trend line. A Floodplain catches; B Volga River catches.

distance changes with inundation magnitude. These results confirm the need for considering the floodplain topography and inundation pathways as essential components in studies of river-floodplain functioning (Ligon and others 1995; Vaughan and others 2009).

The relationship between discharge and inundated floodplain area is highly non-linear and shows considerable anti-clockwise hysteresis. In the initial phase of the flood, the flood water and the area of largest inundation shift in a downstream direction over the floodplain. The upstream parts of the floodplain drain relatively quickly after the peak of the flood, whereas lower-lying eastern parts remain inundated as long as the upstream discharge is above bank-full level. After the river discharge recedes to low levels, the lowest floodplain areas also drain rapidly, and fall dry within a week. The reservoir function of the floodplain is thus small when compared to the drainage capacity of the floodplain channels. The consequence of this process is that the extent and the duration of inundation and, hence, the degree of connection of the floodplain lakes, is to a large extent determined by the total volume of water that has entered the floodplain as soon as the river discharge is above bank-full level. Thus, the flood volume is a better measure for the effective flood-pulse magnitude than the peak height of the flood (compare Frazier and Page 2009; Tockner and others 1999). Ignoring the different inundation and recession phases may result in a considerable uncertainty in the relationship between inundated area and runoff, as was experienced for the Ob river by Papa and others (2007). The quick water recession also implies that the discharge maintained in the weeks after the peak flow is only effective in prolonging floodplain inundation if it is kept above the threshold level for floodplain inundation.

The relative total fish catch in the floodplain increases with a larger extent of floodplain inundation, whereas the Volga River catch does not, despite the fact that similar species are present in both catches. The opposite responses to flood volume of bream and asp catch between the river and floodplain suggest that biomass of the floodplain fish population indeed depends on the inundation magnitude and associated habitat availability and connection, corroborating other studies on fish catch and flooding (Amoros and Roux 1988; De Graaf 2003a; Schramm and Eggleton 2006). Fish species for which the catch increases with flood volume in the floodplain generally have a eurytopic flow preference, with the exception of rheophilic ide and limnophilic tench (Tinca tinca). Most species have a preference for spawning on plants or hard substrate, except for polyphilic common bream and roach that do not have a preference for a specific spawning habitat. In terms of feeding guild, these species use a wide range of food, including detritus, plants, zoobenthos, zooplankton and fish. All in all, a variety of species, across trophic levels, appear to take advantage of a higher flood volume in the floodplain, whereas in the Volga this is only the case for one species (gibel carp), which makes up only $0.7 \%$ of the catch (Table 5).

Besides a positive relationship between flooding and biomass (De Graaf 2003a; Schramm and Eggleton 2006), flooding also provides spawning and nursery habitats for many fishes and is thereby instrumental in the successful recruitment of juvenile fishes (Ligon and others 1995; Grift 2001; Van de Wolfshaar and others 2010). Recruitment success is crucial for the long-term survival of fish populations and, therefore, also for the long-term 
development of fish catches, but the relationship between the number of recruits and the catchable biomass after a number of years may not be straightforward due to density-dependent processes. The relationship between somatic growth and biomass in catches at the end of the growing season is much stronger (De Graaf 2003b; Schramm and Eggleton 2006). Therefore, we focused our study on the effects on biomass although recruitment effects will also play a role in our data. However, because fish do not recruit to catchable size within a year in the Volga-Akhtuba system, this relationship could not be studied in our study, which focuses on year-to-year differences.

The positive relationships between catch and flood volume in our study were found for fish species of diverse flow preferences, spawning and feeding guilds. This implies that the entire fish community in the floodplain takes advantage of the increased habitat availability, which supplies a diversity of flow regimes, spawning substrate and food sources. In contrast, the Volga River fish population seems independent of the flood volume and habitat availability within the floodplain. In general, these results indicate that fish inhabiting the main river do not experience an advantage from floodplain inundation. The limited benefits of increased water levels for the fish in the Volga River might be due to the fact that in the river increased water levels do not increase the available foraging habitat as much as occurs in the floodplain, but rather cause a vertical shift of the littoral zone. Only in the eastern part does overbank flow occur directly from the Akhtuba River channel over a long stretch, whereas for the Volga River floodplain connectivity remains limited to the entrances of the streams and channels (Figure 1). This finding supports a recent study showing that fish spring migration from the Volga and Akhtuba into the floodplain is only modest given the amount of fish present in the floodplain (Górski and others 2010). Together, these results suggest that for the Volga-Akhtuba river-floodplain system the river and its floodplain may be less intertwined than studies for embanked floodplains suggest in terms of the floodplain serving as foraging area for river fish and the river serving as refuge for floodplain fish (Aarts and others 2004). Functions often attributed to the main river in river-floodplain systems, such as refuge for freezing and summer drought, are suggested to be fulfilled by water bodies present within the floodplain for fish species that are not bound to fast flowing waters (rheophilic species). Studies on embanked river-floodplain systems may, therefore, overly consider the main river as primary refugium, and underestimate the role of permanent water bodies such as lakes and side channels within natural floodplains.

Errors in the classification of the satellite images might have resulted in incorrect estimates of the inundated areas. In particular, tall and dense vegetation that is inundated with a shallow depth is likely to be erroneously classified as 'non-inundated'. Consequently, we may have underestimated the inundation extent, but it might be questioned whether such densely vegetated areas with shallow water depth will provide sufficient accessibility for fish to pass. Other studies show that despite these issues, the use of satellite images proved very useful to gain insight in spatial and temporal inundation patterns at large scales (McCarthy and others 2003; Papa and others 2007).

\section{Conclusions}

The positive relationship between (floodplain) fish catch and floodplain inundation extent, and the apparent swift drainage of the floodplain area after the flood water has receded below bankfull indicate that long moderate floods (but still above bankfull) are expected to lead to more extensive floodplain inundation and higher fish biomass than short high floods. Still, year-to-year variability of floods should be promoted for preserving species diversity and fish production (Amoros and Roux 1988; Grift 2001; Amoros and Bornette 2002; Poff and others 2007; Bouvier and others 2009). In large floodplains, such as the Volga-Akhtuba floodplain, floodplain topography and flood volume-controlling flood duration and hydrological distances-determine to what extent floodplain lakes are isolated from the main river. Geographical distance to the river channel and peak flow magnitude appear to be inadequate indicators for this purpose. The results indicate that the ecological functioning of floodplains is not limited to its temporary availability as habitat when connected to the main river channel, but refugia can be present within the floodplain itself. This mechanism should be considered in the management and regulation of large rivers and their floodplain.

\section{ACKNOWLEDGEMENTS}

This study is part of the research programme 'Changing flood pulse dynamics and their impact on fish recruitment in large rivers (Volga, Russia)'. Funding was provided by The Netherlands Organization for Scientific Research (NWO), grant No. 857.00.011/857.00.012. The Schure Beijerinck 
Popping Foundation partly financed the MSc students who worked on this project. The authors would like to thank L.V. van den Bosch and K. Górski for valuable discussions, and Robert Naiman and the anonymous reviewers for comments on the manuscript.

\section{OPEN ACCESS}

This article is distributed under the terms of the Creative Commons Attribution Noncommercial License which permits any noncommercial use, distribution, and reproduction in any medium, provided the original author(s) and source are credited.

\section{REFERENCES}

Aarts BGW, Van den Brink FWB, Nienhuis PH. 2004. Habitat loss as the main cause of the slow recovery of fish faunas of regulated large rivers in Europe: the transversal floodplain gradient. River Res Appl 20:3-23.

Amoros C, Bornette G. 2002. Connectivity and biocomplexity in waterbodies of riverine floodplains. Freshw Biol 47:761-76.

Amoros C, Roux AL. 1988. Interaction between water bodies within the floodplain of large rivers: function and development of connectivity. Münstersche Geographische Arbeiten 29:125-30.

Bouvier LD, Cottenie K, Doka SE. 2009. Aquatic connectivity and fish metacommunities in wetlands of the lower Great Lakes. Can J Fish Aquat Sci 66:933-48.

Bowen ZH, Bovee KD, Waddle TJ. 2003. Effects of flow regulation on shallow-water habitat dynamics and floodplain connectivity. Trans Am Fish Soc 132:809-23.

Chalov RS, Ed. 2004. The lower Volga River bed morphology and channel deformations atlas (Volgograd-Astrakhan). Moscow: Faculty of Geography, Moscow State University; Oceanographic Institute, Russian Academy of Sciences.

De Graaf G. 2003a. Dynamics of floodplain fisheries on Bangladesh, results of 8 years fisheries monitoring in the Compartmentalization Pilot Project. Fish Manage Ecol 10:191-9.

De Graaf G. 2003b. The flood pulse and growth of floodplain fish in Bangladesh. Fish Manage Ecol 10:241-7.

Frazier P, Page K. 2009. A reach-scale remote sensing technique to relate wetland inundation to river flow. River Res Appl 25:836-49.

Gallant AR, Goebel JJ. 1976. Nonlinear regression with autoregressive errors. J Am Stat Assoc 71:961-7.

Górski K, Winter HV, De Leeuw JJ, Minin AE, Nagelkerke LAJ. 2010. Fish spawning in a large temperate floodplain: the role of flooding and temperature. Freshw Biol 55(7):1509-19.

Górski K, Van den Bosch LV, Van de Wolfshaar KE, Middelkoop H, Filipov OV, Zolotarev DV, Vekhov DA, Yakovlev SV, Minin AE, Nagelkerke LAJ, Winter HV, De Leeuw JJ, Buijse, Verreth JAJ. 2011. Post-damming flow regime development in a large floodplain river (Volga, Russian Federation): implications for floodplain inundation and fisheries. River Res Appl. doi:10.1002/rral499.

Grift RE. 2001. How fish benefit from floodplain restoration along the lower River Rhine. PhD thesis, Wageningen University.
Gutreuter S, Bartels AD, Irons K, Sandheinrich MB. 1999. Evaluation of the flood-pulse concept based on statistical models of growth of selected fishes of the Upper Mississippi River system. Can J Fish Aquat Sci 56:2282-91.

Ivanov VV, Korotaev VN, Rimskii-Korsakov NA, Chernov AV. 2006. Atlas of channel deformations in the lower Volga. Water Resour 33(5):535-42.

Janssen JAM, Drost HJ, Doze J. 2000. Ecotopenkartering van de Wolga-Akhtuba-riviervlakte. GeoNieuws 2000-4:6-10 (in Dutch).

Junk WJ, Bayley PB, Sparks RE. 1989. The flood pulse concept in river-floodplain systems. Can Spec Publ Fish Aquat Sci 106:110-27.

Karssenberg D, Burrough PA, Sluiter R, de Jong K. 2001. The PCRaster software and course materials for teaching numerical modelling in the environmental sciences. Trans GIS 5(2):99-110.

Levashova J, Mikhailov VN, Aleshkin SA, Mikhailova MV. 2004. Hydrological-morphological processes in the river mouths as indicator of large-scale changes in rivers and seas regime. In: Proc. VI All-Russia hydrologic gathering, St. Petersburg.

Ligon FK, Dietrich WE, Trush WJ. 1995. Downstream ecological effects of dams. Bioscience 45:183-92.

Lillesand TM, Kiefer RW, Chipman JW. 2008. Remote sensing and image interpretation. 6th edn. New York: John Wiley $\delta$ Sons.

McCarthy JM, Gumbricht T, McCarthy T, Frost P, Wessels K, Seldel F. 2003. Flooding patterns of the Okavango Wetland in botswana between 1972 and 2000. Ambio 32(7):453-7.

Middelkoop H, Ed. 2005. Large European River system responses to global change and human adtivities. Final report of the NWO-RFBR project nr. 047.014.010. Utrecht/Moscow/Arnhem: NCR-report 27-2005.

Middelkoop H, Schoor MM, Babich DB, Alabyan AM, Shoubin MA, van den Berg JH, de Kramer J, Dijkstra J. 2005. Biomorfodynamics of the Lower Volga River-a reference for river rehabilitation in the Netherlands. Archiv für Hydrobiologie 155 Large Rivers 15(1-4):89-104.

Miranda LE. 2005. Fish assemblages in oxbow lakes relative to connectivity with the Mississippi River. Trans Am Fish Soc 134:1480-9.

Papa F, Prigent C, Rossow WB. 2007. Ob' River flood inundations from satellite observations: a relationship with winter snow parameters and river runoff. J Geophys Res 112:D18103.

Poff NL, Allan JD, Bain MB, Karr JR, Prestegaard KL, Richter BD, Sparks RE, Stromberg JC. 1997. The natural flow regime. Bioscience 47:769-84.

Poff NL, Olden JD, Merritt DM, Pepin DM. 2007. Homogenization of regional river dynamics by dams and global biodiversity implications. Proc Natl Acad Sci USA 104:5732-7.

Probst WN, Stoll S, Peters L, Fischer P, Eckmann R. 2009. Lake water level increase during spring affects the breeding success of bream Abramis brama (L.). Hydrobiologia 632:211-24.

Ratkovich DY, Vyruchalkina TY, Solomonova IV. 2003. Fishery water releases to the lower pool of the Volgograd hydroelectric power plant. Water Resour 30:426-42.

SAS Institute Inc. 2004. SAS OnlineDoc ${ }^{\circledR}$ 9.1.3. Cary, NC: SAS Institute Inc.

Schramm HJR, Eggleton MA. 2006. Applicability of the floodpulse concept in a temperate floodplain river ecosystem: thermal and temporal components. River Res Appl 22:543-53. 
Sommer TR, Nobriga ML, Harrell WC, Batham W, Kimmerer WJ. 2001. Floodplain rearing of juvenile chinook salmon: evidence of enhanced growth and survival. Can J Fish Aquat Sci 58:325-33.

Tockner K, Pennetzdorfer D, Reiner N, Schiemer F, Ward JV. 1999. Hydrological connectivity, and the exchange of organic matter and nutrients in a dynamic river-floodplain system (Danube, Austria). Freshw Biol 41:521-35.

Van de Wolfshaar KE, Ruizeveld de Winter AC, Straatsma MW, Van den Brink NGM, De Leeuw JJ. 2010. Estimating spawning habitat availability in flooded areas of the river Waal, The Netherlands. River Res Appl 26:487-98.

Vasilevskii AG, Veksler AB, Deryugin GK, Donenberg VM, Shvainshtein AM. 2001. Safety problems in the transmission of the design flows through the hydrosystems of the VolgaKama cascade. Hydrotech Constr 35:572-8.

Vaughan IP, Diamond M, Gurnell AM, Hall KA, Jenkins A, Milner NJ, Naylor LA, Sear DA, Woodward G, Ormerod SJ. 2009. Integrating ecology with hydromorphology: a priority for river science and management. Aquat Conser Mar Freshw Ecosyst 19:113-25.

Vinod HD. 1973. Generalization of the Durbin-Watson statistic for higher order autoregressive process. Commun Stat 2:11544.

Vörösmarty CJ, Fekete BM, Tucker BA. 1998. Global River Discharge, 1807-1991, V. 1.1 (RivDIS). Oak Ridge, TN: Oak Ridge National Laboratory Distributed Active Archive Center. Data set. Available on-line. http://www.daac.ornl.gov. 